\title{
Congenital infection with Anaplasma phagocytophilum in a calf in northern Germany
}

\author{
Thomas Henniger ${ }^{1}$, Pauline Henniger ${ }^{1}$, Thekla Grossmann², Ottmar Distl ${ }^{1}$, Martin Ganter ${ }^{2}$ \\ and Friederike $D$ von Loewenich ${ }^{3^{*}}$
}

\begin{abstract}
Anaplasma phagocytophilum is a Gram-negative, obligate intracellular tick-transmitted bacterium that replicates in neutrophils. It causes tick-borne fever (TBF) in sheep and cattle, but also elicits febrile disease in humans as well as in other domestic animals such as dogs, horses, and cats. Although increasingly recognized in Europe, the first laboratory-confirmed case of TBF in cattle from Germany has been published only recently. We here present the unusual case of an intrauterine transmission of A. phagocytophilum in a calf from northern Germany. To our knowledge, this is the first report of such an event occurring under field conditions in cattle.
\end{abstract}

Keywords: Anaplasma phagocytophilum, Intrauterine infection, Tick-borne fever, Cattle, Germany

\section{Background}

Anaplasma phagocytophilum is a Gram-negative, obligate intracellular tick-transmitted bacterium that replicates in neutrophils [1]. It was initially recognized as the causative agent of tick-borne fever (TBF) in sheep and cattle [2,3], but also causes febrile disease in dogs [4], horses [5], cats [6], and humans [1]. As a result of taxonomic changes in 2001, A. phagocytophilum comprises the former species Ehrlichia phagocytophila, E. equi, and the agent of human granulocytic ehrlichiosis [7]. However, this unification has been a matter of debate, because naturally circulating $A$. phagocytophilum strains are not equally infectious for different mammalian species $[8,9]$. The main vector of $A$. phagocytophilum in Europe is Ixodes ricinus [10]. Clinical symptoms in cattle include high fever, reduced milk yield, inappetence, cough, and abortion [10]. Leukopenia, thrombocytopenia, and anemia are typical laboratory findings [11]. The diagnosis is made from peripheral blood via microscopic detection of bacterial inclusions in granulocytes, so-called morulae, or by species-specific polymerase chain reaction (PCR) [12]. In contrast, the significance of serological tests is very limited, because they do not distinguish between recent or past infections [13]. Although

\footnotetext{
* Correspondence: friederike.loewenich@uniklinik-freiburg.de

${ }^{3}$ Institute of Medical Microbiology and Hygiene, University of Freiburg,

Hermann-Herder-Strasse 11, D-79104 Freiburg, Germany

Full list of author information is available at the end of the article
}

increasingly recognized in Europe, the first laboratoryconfirmed case of TBF in cattle from Germany has been published only recently [14]. We here report an unusual case of intrauterine transmission of $A$. phagocytophilum to a calf.

\section{Case presentation}

\section{Clinical signs}

In June 2011, a male Holstein-Friesian calf was obtained immediately after birth from a dairy farm in Lower-Saxony for inclusion in a study investigating the pathogenesis of alloantibody-induced bovine neonatal pancyotopenia (BNP) [15]. The dam was born in January 2007 and raised on the farm. She calved for the first time in 2009 and aborted in 2010 after her second mating. Thereafter, in September 2010 the cow was artificially inseminated. From May 2011 she was grazed on pasture. With the exception of an intramammary antibiotic treatment, the cow did not receive any systemic antimicrobials.

The animal experiments investigating BNP were approved by the Animal Welfare Committee of the Niedersächsisches Landesamt für Verbraucherschutz und Lebensmittelsicherheit, Oldenburg (reference number: 33.9-42502-04-09/1799). EDTA blood and serum samples were collected from the precolostral calf and its mother. The calf was then fed with colostrum that was known to induce BNP. Since its first day of life, the calf 
Table 1 Rectal temperatures and blood cell counts of the calf and its mother

\begin{tabular}{|c|c|c|c|c|c|c|c|c|c|}
\hline \multirow[b]{2}{*}{ Day after birth } & \multirow{2}{*}{$\begin{array}{c}\text { Reference } \\
\text { values calves }\end{array}$} & \multicolumn{6}{|c|}{ Calf } & \multirow{3}{*}{$\begin{array}{c}\text { Reference } \\
\text { values cattle }\end{array}$} & \multirow{3}{*}{$\begin{array}{c}\text { Dam } \\
4 \\
\text { nd }\end{array}$} \\
\hline & & 0 & 0 & 1 & 2 & 3 & 4 & & \\
\hline Time & & 02:00 & $19: 30$ & 08:30 & $08: 30$ & $08: 30$ & 11:00 & & \\
\hline Rectal temperature $\left({ }^{\circ} \mathrm{C}\right)$ & $38.5-39.5$ & nd & 40.1 & 39.8 & 39.9 & 40.1 & 39.9 & $38.0-39.0$ & nd \\
\hline Hemoglobin $(\mathrm{g} / \mathrm{l})$ & $75-120$ & 125 & nd & 97 & 80 & 59 & 40 & $80-120$ & 139 \\
\hline Packed cell volume (I/I) & $0.22-0.46$ & 0.40 & nd & 0.30 & 0.24 & 0.18 & 0.12 & $0.28-0.39$ & 0.40 \\
\hline Red blood cell count $\left(\times 10^{12} / \mathrm{l}\right)$ & $6.0-10.0$ & 9.14 & nd & 7.16 & 5.77 & 4.44 & 2.91 & $5.0-8.0$ & 6.76 \\
\hline Reticulocytes (\%o) & $0-10$ & 0 & nd & 0 & 0 & 0 & 3 & $0-10$ & 1 \\
\hline Thrombocytes (x 109/I) & $200-1300$ & 180 & nd & 15 & 14 & 3 & 23 & $200-800$ & 323 \\
\hline White blood cell count $\left(\times 10^{9} / \mathrm{l}\right)$ & $4.0-14.0$ & 4.9 & nd & 1.5 & 1.7 & 3.2 & 2.7 & $5.0-10.0$ & 10.5 \\
\hline Lymphocytes $\left(\times 10^{9} / \mathrm{l}\right)$ & $2.5-5.5$ & 1.81 & nd & 0.50 & 0.44 & 0.32 & 0.26 & $2.5-5.5$ & 5.72 \\
\hline Monocytes (x 109/l) & $0.2-0.8$ & 0.17 & nd & 0.03 & 0.00 & 0.00 & 0.00 & $0.2-0.8$ & 0.52 \\
\hline Segmented neutrophils $\left(\times 10^{9} /\right)$ & $2.5-4.5$ & 2.87 & nd & 0.72 & 0.99 & 2.21 & 0.99 & $2.5-4.5$ & 3.88 \\
\hline Band neutrophils $\left(\times 10^{9} / \mathrm{l}\right)$ & $0.0-0.2$ & 0.05 & nd & 0.24 & 0.27 & 0.67 & 1.17 & $0.0-0.2$ & 0.37 \\
\hline Eosinophils $\left(\times 10^{9} / \mathrm{l}\right)$ & $0.3-0.9$ & 0.00 & nd & 0.02 & 0.00 & 0.00 & 0.00 & $0.3-0.9$ & 0.00 \\
\hline Neutrophils with morulae (\% of the examined 400 ) & 0 & * & nd & $60^{* *}$ & 53 & 47 & 56 & 0 & 0 \\
\hline
\end{tabular}

${ }^{+}[16,17]$, nd $=$ not determined, ${ }^{*}$ not definable due to cell damage, ${ }^{* *} 30 \%$ of lymphocytes and some monocytes also infected.

showed elevated rectal temperatures of at least $39.8^{\circ} \mathrm{C}$. In contrast to the other animals from the same experimental group that developed BNP 3 to 4 days after birth, the calf already showed typical signs of BNP such as cutaneous hemorrhages, mucosal petechial hemorrhages, and melena from its second day of life onwards. Similarly, thrombocytopenia, leukopenia, and anemia developed rapidly (Table 1). At the age of 4 days, the calf was euthanized, because it stopped drinking and showed severe deterioration in its general condition and persistent recumbency. Because the dam was asymptomatic, she was not medicated.

\section{Laboratory test results}

Results of blood counts and the course of the rectal temperature of the calf are shown in Table 1. In a Giemsa-stained smear of precolostral EDTA blood, morulae of A phagocytophilum were detected in neutrophil granulocytes (Figure 1A). One day after birth, morulae were not only found in $60 \%$ of the 400 examined neutrophils, but also in $30 \%$ of the lymphocytes (Figure 1B) and in some monocytes. Blood smears remained positive for A. phagocytophilum until the calf was euthanized. Maternal blood smears were microscopically negative.

The diagnosis was confirmed by amplification and sequencing of the 16S rRNA gene of A. phagocytophilum from blood samples taken on days 3 and 4 after birth as described previously $[18,19]$. The $16 \mathrm{~S}$ rRNA gene sequence was identical to an A. phagocytophilum variant [GenBank: M73220] well-known mainly from ruminant infections. EDTA blood samples from the dam taken at parturition and 2 days postpartum contained the same

$16 \mathrm{~S}$ rRNA genotype. At day 19 postpartum, the dam was found to be negative for A. phagocytophilum DNA.

Serum samples from both animals were investigated by an indirect immunofluorescence test (IFT) (Focus Diagnostics, Cypress, CA, USA) using FITC-conjugated goat anti-bovine $\operatorname{IgG}(\mathrm{H}+\mathrm{L})$ antibody (Dianova, Hamburg, Germany) as secondary antibody. Serum from the 2-dayold calf was negative for anti-A. phagocytophilum antibodies, whereas the cow had a titer of 1:256 (cut-off: 1:64) on days 2 and 19 post partum.

To determine whether both animals were infected by the same strain of $A$. phagocytophilum, the ankA gene as a further genotypic marker was amplified as described previously $[20,21]$. Unexpectedly, two ank $A$ gene sequences belonging to two different clusters, I and IV [21] were amplified from the calf's blood at days 3 and 4

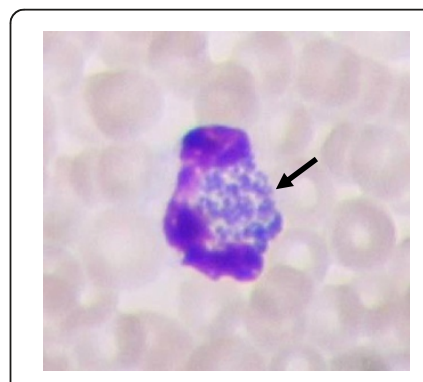

A

Figure 1 Morulae (arrow) of Anaplasma phagocytophilum in Giemsa-stained blood smears of the calf. Morulae in a neutrophil in a blood smear at 2 hours after birth. (A). Morulae in a lymphocyte in a blood smear at day 1 after birth (B). Magnification: $10 \times 100$. 
after birth. In contrast, the dam was infected with $A$. phagocytophilum carrying only the ankA gene variant of cluster I in blood samples taken at parturition and 2 days postpartum. The cluster I ankA sequences of both animals were $100 \%$ identical. To confirm that both animals were infected with the same $A$. phagocytophilum strain, multi locus sequence typing (Winter C, Huhn C, Wolfsperger T, Wüppenhorst N, von Loewenich FD: unpublished observations) was applied and revealed the same sequence type 140 in mother and calf. An overview of the A. phagocytophilum-specific test results is shown in Table 2. 16S rRNA and ankA gene sequences are available under the following accession numbers: [GenBank: KC776917 - KC776921].

\section{Discussion}

Although TBF in cattle is known to cause abortion or stillbirth [10], to our knowledge a spontaneously occurring intrauterine infection of a bovine fetus with $A$.

Table 2 Summary of Anaplasma phagocytophilum-specific test results

\begin{tabular}{|c|c|c|}
\hline $\begin{array}{l}\text { Day } \\
\text { after birth }\end{array}$ & Calf & Dam \\
\hline \multirow[t]{4}{*}{0} & - morulae in blood smear & - microscopically negative \\
\hline & & $\begin{array}{c}\text { - 16S rRNA gene identical to } \\
\text { [GenBank: M73220] }\end{array}$ \\
\hline & & $\begin{array}{l}\text { - detection of ankA cluster } \\
\text { IV }\end{array}$ \\
\hline & & - sequence type 140 \\
\hline 1 & - morulae in blood smear & \\
\hline \multirow[t]{5}{*}{2} & - morulae in blood smear & - microscopically negative \\
\hline & $-\mathrm{IFT}<1: 64$ & $\begin{array}{c}\text { - 16S rRNA gene identical to } \\
\text { [GenBank: M73220] }\end{array}$ \\
\hline & & $\begin{array}{l}\text { - detection of ankA cluster } \\
\text { IV }\end{array}$ \\
\hline & & - sequence type 140 \\
\hline & & - IFT 1: 256 \\
\hline
\end{tabular}

\begin{tabular}{|c|c|c|}
\hline \multirow[t]{4}{*}{3} & - morulae in blood smear & \\
\hline & $\begin{array}{c}\text { - 16S rRNA gene identical to } \\
\text { [GenBank: M73220] }\end{array}$ & \\
\hline & $\begin{array}{l}\text { - detection of ankA cluster I } \\
\text { and ankA cluster IV }\end{array}$ & \\
\hline & - sequence type 140 & \\
\hline \multirow[t]{4}{*}{4} & - morulae in blood smear & - microscopically negative \\
\hline & $\begin{array}{c}\text { - 16S rRNA gene identical to } \\
\text { [GenBank: M73220] }\end{array}$ & \\
\hline & $\begin{array}{l}\text { - detection of ankA cluster I } \\
\text { and ankA cluster IV }\end{array}$ & \\
\hline & - sequence type 140 & \\
\hline \multirow[t]{3}{*}{19} & & - microscopically negative \\
\hline & & - 165 rRNA gene negative \\
\hline & & - IFT 1:256 \\
\hline
\end{tabular}

phagocytophilum has not been reported to date. In our case, evidence for an intrauterine infection comes from the fact that a significant proportion of neutrophils in the blood smear of the calf prepared 2 hours after birth were already infected. Furthermore, the calf was not tick-exposed during its short lifetime. It has been shown that oral transmission of $A$. phagocytophilum is inefficient in cattle [22], whereas it has been proven experimentally that intrauterine infection does occur [23]. That study showed absence of specific fetal antibodies in a calf delivered 17 days after the mother was experimentally infected and that the calf did not seroconvert until it was 26 days old [23]. The calf reported in the present case was likewise seronegative. Based on these circumstances, it seems most likely that it was infected in utero. It has been shown experimentally that adult cattle develop elevated antibody titers of $>1: 320$ at day 14 post infection and remain PCR-positive for $A$. phagocytophilum on average until day 22 [11]. Because the dam was PCR positive and showed an antibody titer of 1:256 at day 2 after parturition, we suggest that she had been infected 2 to 3 weeks earlier. As far as reported by the farmer the dam was clinically asymptomatic, but the symptoms that typically last for 1 week [11] might have gone unrecognized.

The molecular characterization of the A. phagocytophilum strain proved that mother and calf were infected with the same strain. However, two ankA gene variants were found reproducibly in the calf's blood. The possibility exists that the dam initially transmitted two strains that were not distinguishable apart from their ankA genes and that she had already cleared one of them at the time of delivery. It might also be that the bacterial burden of one of the strains had already fallen below the detection limit. Alternatively, intra-species recombination, as has been hypothesized earlier [21], could have taken place leading to the appearance of two $a n k A$ gene variants in the calf's blood.

\section{Conclusions}

A spontaneous bovine congenital infection with $A$. phagocytophilum is reported for the first time. Intrauterine infection of cattle has previously been produced experimentally, but this study confirms that this may also occur under field conditions.

\section{Consent}

Written informed consent was obtained from the owner for publication of this report.

\footnotetext{
Abbreviations

BNP: Bovine neonatal pancytopenia; IFT: Indirect immunofluorescence test; PCR: Polymerase chain reaction; TBF: Tick-borne fever.
} 


\section{Competing interests}

The authors declare that they have no competing interests.

\section{Authors' contributions}

$\mathrm{TH}$ and $\mathrm{PH}$ did the clinical investigation. $\mathrm{TG}, \mathrm{MG}$, and FvL performed the laboratory tests. TH, OD, MG, and FVL prepared the manuscript. All authors have read and approved its final version.

\section{Acknowledgements}

This study was partly funded by the German Federal Institute for Agriculture and Nutrition (BLE), Bonn (grant $2810 \mathrm{HSO} 25$ to OD). The article processing charge was funded by the German Research Foundation (DFG) and the Albert-Ludwigs-University Freiburg in the funding programme Open Access Publishing. The authors are grateful to Lesley Bell-Sakyi (The Tick Cell Biobank, The Pirbright Institute, Pirbright, United Kingdom) and Nicole Wüppenhorst (Institute of Medical Microbiology, University of Freiburg, Freiburg, Germany) for critical reading of the manuscript.

\section{Author details}

${ }^{1}$ Institute for Animal Breeding and Genetics, University of Veterinary Medicine Hannover, Bünteweg 17p, D-30559 Hannover, Germany. ${ }^{2}$ Clinic for Swine and Small Ruminants, University of Veterinary Medicine Hannover, Bischofsholer Damm 15, D-30173 Hannover, Germany. ${ }^{3}$ Institute of Medical Microbiology and Hygiene, University of Freiburg, Hermann-Herder-Strasse 11, D-79104 Freiburg, Germany.

Received: 19 March 2013 Accepted: 22 April 2013

Published: 1 May 2013

\section{References}

1. Ismail N, Bloch KC, McBride JW: Human ehrlichiosis and anaplasmosis. Clin Lab Med 2010, 30:261-292.

2. Gordon WS, Brownlee A, Wilson DR, MacLeod J: Tick-borne fever (a hitherto undescribed disease of sheep). J Comp Pathol 1932, 45:301-312.

3. Hudson JR: The recognition of tick-borne fever as a disease of cattle. Brit Vet J 1950, 106:3-17.

4. Carrade DD, Foley JE, Borjesson DL, Sykes JE: Canine granulocytic anaplasmosis: a review. J Vet Intern Med 2009, 23:1129-1141.

5. Madigan JE, Pusterla N: Ehrlichial diseases. Vet Clin N Am Equine Pract 2000, 16:487-499

6. Little SE: Ehrlichiosis and anaplasmosis in dogs and cats. Vet Clin North Am Small Anim Pract 2010, 40:1121-1140.

7. Dumler JS, Barbet AF, Bekker CPJ, Dasch GA, Palmer GH, Ray SC, Rikihisa Y, Rurangirwa FR: Reorganization of genera in the families Rickettsiaceae and Anaplasmataceae in the order Rickettsiales: unification of some species of Ehrlichia with Anaplasma, Cowdria with Ehrlichia and Ehrlichia with Neorickettsia, descriptions of six new species combinations and designation of Ehrlichia equi and 'HGE agent' as subjective synonyms of Ehrlichia phagocytophila. Int J Syst Evol Microbiol 2001, 51:2145-2165.

8. Rar V, Golovljova I: Anaplasma, Ehrlichia, and "Candidatus Neoehrlichia" bacteria: pathogenicity, biodiversity, and molecular genetic characteristics, a review. Infect Genet Evol 2011, 11:1842-1861.

9. Jin H, Wei F, Liu Q, Qian J: Epidemiology and control of human granulocytic anaplasmosis: a systematic review. Vector Borne Zoonotic Dis 2011, 12:269-274

10. Woldehiwet Z: The natural history of Anaplasma phagocytophilum. Vet Parasitol 2010, 167:108-122.

11. Pusterla N, Huder J, Wolfensberger C, Braun U, Lutz H: Laboratory findings in cows after experimental infection with Ehrlichia phagocytophila. Clin Diagn Lab Immunol 1997, 4:643-647.

12. Woldehiwet $Z$ : Anaplasma phagocytophilum in ruminants in Europe. Ann N Y Acad Sci 2006, 1078:446-460.

13. Aguero-Rosenfeld M: Diagnosis of human granulocytic ehrlichiosis: state of the art. Vector Borne Zoonotic Dis 2002, 2:233-239.

14. Nieder M, Silaghi C, Hamel D, Pfister K, Schmäschke R, Pfeffer M: Tick-borne fever caused by Anaplasma phagocytophilum in Germany: first laboratory confirmed case in a dairy cattle herd. Tierarztl Prax Ausg G Grosstiere Nutztiere 2012, 40:101-106.

15. Schröter P, Kuiper H, Holsteg M, Puff C, Haas L, Baumgärtner W, Ganter M, Distl O: Reproducibility of bovine neonatal pancytopenia (BNP) via the application of colostrum. Berl Munch Tierarztl Wochenschr 2011, 124:390-400.
16. Mohri M, Sharifi K, Eidi S: Hematology and serum biochemistry of Holstein dairy calves: age related changes and comparison with blood composition in adults. Res Vet Sci 2007, 83:30-39.

17. Gründer H-D: Krankheiten des Blutes. In Innere Medizin und Chirurgie des Rindes. 5th edition. Edited by Stöber M, Gründer H-D, Dirksen G. Stuttgart: Parey; 2006:202-266.

18. Massung RF, Slater K, Owens JH, Nicholson WL, Mather TN, Solberg VB, Olson JG: Nested PCR assay for detection of granulocytic ehrlichiae. J Clin Microbiol 1998, 36:1090-1095.

19. von Loewenich FD, Baumgarten BU, Schröppel K, Geißdörfer W, Röllinghoff M, Bogdan C: High diversity of ankA sequences of Anaplasma phagocytophilum among Ixodes ricinus ticks in Germany. J Clin Microbiol 2003, 41:5033-5040.

20. Massung RF, Owens JH, Ross D, Reed KD, Petrovec M, Bjöersdorff A, Coughlin RT, Beltz GA, Murphy Cl: Sequence analysis of the ank gene of granulocytic Ehrlichiae. J Clin Microbiol 2000, 38:2917-2922.

21. Scharf W, Schauer S, Freyburger F, Petrovec M, Schaarschmidt-Kiener D, Liebisch G, Runge M, Ganter M, Kehl A, Dumler JS, et al: Distinct host species correlate with Anaplasma phagocytophilum ankA gene clusters. J Clin Microbiol 2011, 49:790-796.

22. Pusterla N, Huder J, Wolfensberger C, Lutz H, Braun U: Experimental oral transmission of Ehrlichia phagocytophila to calves. Vet Rec 1998, 143:250-251.

23. Pusterla N, Braun $U$, Wolfensberger C, Lutz H: Intrauterine infection with Ehrlichia phagocytophila in a cow. Vet Rec 1997, 141:101-102.

doi:10.1186/1751-0147-55-38

Cite this article as: Henniger et al:: Congenital infection with Anaplasma phagocytophilum in a calf in northern Germany. Acta Veterinaria Scandinavica 2013 55:38.

\section{Submit your next manuscript to BioMed Central and take full advantage of:}

- Convenient online submission

- Thorough peer review

- No space constraints or color figure charges

- Immediate publication on acceptance

- Inclusion in PubMed, CAS, Scopus and Google Scholar

- Research which is freely available for redistribution 